\title{
Effects of Training Strategies on Employees Performance: A Practical Study in Amman's Municipality $\backslash$ Jordan
}

\author{
Dr. Rawan Odehalshawabkeh \\ Al- Ahliyya Amman University \\ Jordan \\ Dr. Ayyoub Alsawalhah \\ The World Islamic Sciences \& Education University \\ Jordan
}

\begin{abstract}
This paper aimed at studying the effect of training Strategies on employees performance as a practical study from Amman's Municipality employees' perspective $\backslash o r d a n$, it consisted of (550) individual which is the number of all employees. A random sample of (250) individuals was taken \& the number of valid feedback questionnaires was (201).The questionnaires' data were processed using (SPSS): the researchers found that training strategies implementation at Amman's Municipality was average level \& the employees' performance too an average level. Hypothesis study results have shown a statistical effect at level $(\alpha \leq 0,05)$ of training Strategies on employees' performance. Recommendations based on the study findings: To establish training needs regularly to all employees at Amman's Municipality, to increase the budget of Training.
\end{abstract}

Keywords: Training, Training Strategies, Employees performance, Jordan\Amman's Municipality.

\section{1- Introduction}

Training strategy proved to be an effective way to solve a lot of problems experienced by organizations in a variety of ranges, specifically in human resources development (Guest, 2011). Most of administrators have regularly developed the idea of training as an essential way to keep organizations effective and vigorous shown by the huge budgets allocated for training. Successful training should have a strict sense of training to those concerned with the trainer, trainee or the training supervisor, as it has a tremendous effect on proper preparation \& implementation of training courses, wherefore organizations shall provide the latest training techniques as to optimize their employee's potentials (Datta., Guthrie, \& Wright, 2005).Employees' performance is an important necessity these days in the workplace, as organizations success depends on it. Modern organizations are looking for efficient employees as a major source of competitive advantage in business environment. In the area of strategic human resources management, researchers argue that in today's complex and dynamic environment, organizations need flexibility to adapt to diverse and changing requirements (Snow and Snell, 1993).

2-Research problem: This study begins from the realization of the need to effectively administer the effect of training strategies on employee performance at Amman's Municipality. Researches proved a negative perception of employees toward the efficiency of training strategies elements; they were dissatisfied with varying degrees.As their annual assessment proved that there are obstacles faced in improving employees' performance which requires activating training strategies to enhance employees' performance.

\section{3- The Study Hypotheses:}

The main hypothesis :There is no statistical significance effect of Training Strategies on Employees Performance at Amman's Municipality..

\section{The following are the sub-hypothesis:}

Ho1-1: There is no statistical significance effect of training process stages on employees' performance at Amman Municipality.

Ho1-2: There is no statistical significance effect for the diversity of training programs on employees' performance at Amman Municipality

Ho1-3: There is no statistical significance effect of adopting \& using modern technologies of training on employees' performance at Amman's Municipality. 
Ho1-4: There is no statistical effect at significance level of Support and commitment of senior management on employees' performance at Amman's Municipality.

\section{4-The previous literature}

\section{4 -Training Strategies}

Training is defined as "a planned process of adjusting the situation, knowledge, skill or behavior through the learning experience to achieve effective performance in an activity or set of activities." The purpose of the training is to develop the capacity of individuals and meet the current and future needs of the organization, (Wilson, 1999, p. 4). According to dynamic developments in all areas of work, the organization must develop their human resources to strategic human resources, because organizations can not apply a strategic training plan unless they have a human resources management system in place. In the strategic literature on human resources management, strategic training is a vital means of increasing staff efficiency (Richard et al., 2009). According to Armstrong (2000), strategic human resource management (SHRM) emphasizes longer-term issues of people and consequently long-term training strategies. SHRM should provide appropriate support mechanisms and address personal attitudes and motivation within organizations to ensure participation and support. However, organizations can also achieve immediate improvements in performance by using short-term management approaches for effective training programs (Thomas, 2000).

\subsection{4: Training Strategy Concept}

The following are some of the Human resource training strategies: (Armstrong, 2009)

- To structure moral \& bonus plan to motivate competence workers.

- The training program must meet expectations and needs of the employees to reduce labour turnovers.

- Ensure balance for employees in regard of performance assessment, bonus system \& training.

- In forming training strategy as derived from achieving human resources objectives; organizations shall adopt training \& developing programs to all administrative divisions, to ensure employees efficiency to meet with its different duties \& responsibilities.

- $\quad$ Making a good hiring decision to get benefit of specialized experiences.

- $\quad$ To build a positive work environment \& Enhance Productivity.

2.1.4 : The four basics steps in the training strategic approach (Boudreau, \& Ramstad, 2003):

- The external environment influence: the external environment influences the organization's activities in various ways which presents a number of opportunities \& threats, represented in legal, economic, political \& technologic conditions, therefore the training strategy needs to be able to respond early to the external environment; to take advantage of available opportunities \&avoid external threats.

- Align Training with Mission Goals: an organization message is the unique characteristics that distinguish it from other competitor organizations in the market through allocating its recourses. The training strategy contributes in achieving the organization objectives through enhancing human recourses performance.

- Making objective decisions to achieve it: these goals represent the contributing methods the organization needs to achieve its message \&evident work procedures can be measured, as in this frame work the organization faces a lot of strategic choices in enhancing employees" performance, therefore they must make a clear \& strict decision in this regard.

- To admit the human recourses market movement $\&$ the considerable competition, adding to the advantages that could be achieved to the organization.

3.1.4: Preparing stages of training strategy (Fombrun., Tichy, Devanna, 2015):

- The Organization strategy analysis: Message, goals, duties, policies \&programs.

- The Organization's Internal Environment Analysis: the organization current status, work process average, employees' efficiency \& future needs.

- The external environment Analysis: Economic, political \& technologic \& legal conditions, demographic factors, competition \& globalization.

- Preparing \& Strategy Formulation: Policies, Programs \& Budgets to be integrated with the organization strategy.

- The training strategy plan must be revised to cope with any changes in the internal \& external environment.

\section{4: Employees Performance}

The job related activities expected of a worker and how well those activities were executed, it is the result of efforts, skills \& to identify the role required (Armstrong, 2006). 
It's also defined according to efficiency concept as an internal performance represented by the human recourses quantity used in producing one unit of outcomes, meanwhile its defined as an external performance exemplified in organizations outcomes \& goals to be achieved. (Youndt., Snell, Dean, and Lepak, 1996) .

\section{5- $\quad$ Test the hypotheses of the study}

\section{The main Hypothesis:}

Ho1: There is no statistical effect at significance level $(\alpha \leq 0$, 05of Training Strategies on Employees Performance at Amman's Municipality.

Multiple Regressions analysis wasused to test the hypothesis, the results are:

Table ( 1 ): Test results of Effects of Training Strategies on Employees Performance

\begin{tabular}{|c|c|c|c|c|c|c|c|c|c|}
\hline \multirow[b]{2}{*}{$\begin{array}{l}\text { Dependent } \\
\text { Variable }\end{array}$} & \multicolumn{2}{|c|}{ Model Summary } & \multicolumn{2}{|c|}{ ANOVA } & \multicolumn{5}{|l|}{ Coefficient } \\
\hline & $\begin{array}{l}\mathrm{R}^{2} \\
\text { Pearson } \\
\text { Correlation } \\
\text { Coefficient }\end{array}$ & $\begin{array}{l}\mathrm{R} \\
\text { determination }\end{array}$ & Sig F & $\begin{array}{l}\mathrm{F} \\
\text { Calculated }\end{array}$ & variance & B & $\begin{array}{l}\text { Standard } \\
\text { error }\end{array}$ & $\mathrm{T}$ & Sig t \\
\hline $\begin{array}{l}\text { Employees } \\
\text { Performance }\end{array}$ & 0,606 & 0,367 & 25,250 & 0,000 & $\begin{array}{l}\text { Training } \\
\text { Process } \\
\text { Stages }\end{array}$ & 0,108 & 0,049 & 2,207 & 0,029 \\
\hline & & & & & $\begin{array}{l}\text { diversity of } \\
\text { training } \\
\text { programs }\end{array}$ & 0,154 & 0,052 & 2,963 & 0,003 \\
\hline & & & & & $\begin{array}{l}\text { adopting \& } \\
\text { using } \\
\text { modern } \\
\text { technologies }\end{array}$ & 0,143 & 0,052 & 2,722 & 0,007 \\
\hline & & & & & $\begin{array}{l}\text { Support and } \\
\text { commitment } \\
\text { of senior } \\
\text { management }\end{array}$ & 0,178 & 0,047 & 3,738 & 0,000 \\
\hline
\end{tabular}

The Effect significance level $(\alpha \leq 0,05)$

The results of the table (1) indicate that Pearson Correlation Coefficient $(\mathrm{R}=0,606)$ refers to the relationship between the independent variables and the dependent variable, the effect of the independent variables (dimensions of training strategy) on the dependent variable (Employees Performance) is statistical significance, where the calculated value of $\mathrm{F}$ is $(25,250)$, with significance level of $\left(0,000=\right.$ and is less than 0,05 , where the value of determination coefficient is $\left(R^{2}\right.$ $=0,367)$ and it indicates that $(36,7 \%)$ of the variation in the (Employees Performance) can be explained by the variation in the combined dimensions of training strategy. And in order to test the hypotheses of the main hypothesis, simple linear regression analysis was applied and the results were as follows:

1-Ho:There is no statistical significance effect of training process stages on employees' performance at Amman Municipality.

The table (2): results of the impact test of training process stages on employees' performance at Amman Municipality.

\begin{tabular}{|l|l|l|l|l|l|l|l|l|l|}
\hline & \multicolumn{2}{|l|}{ Model summery } & \multicolumn{2}{|l|}{ ANOVA } & \multicolumn{2}{l|}{ Coefficient } \\
\cline { 2 - 8 } $\begin{array}{l}\text { Dependent } \\
\text { Variable }\end{array}$ & $\begin{array}{l}\mathrm{R} \\
\text { Pearson } \\
\text { Correlation } \\
\text { Coefficient }\end{array}$ & $\begin{array}{l}\mathrm{R}^{2} \\
\text { determination }\end{array}$ & Sig F & $\begin{array}{l}\mathrm{F} \\
\text { Calculated }\end{array}$ & variance & $\mathrm{B}$ & $\begin{array}{l}\text { standard } \\
\text { error }\end{array}$ & $\mathrm{T}$ & Sig t \\
\hline $\begin{array}{l}\text { Employees } \\
\text { Performance }\end{array}$ & 0,441 & 0,194 & 42,615 & 0,000 & $\begin{array}{l}\text { training } \\
\text { process } \\
\text { stages }\end{array}$ & 0,288 & 0,044 & 6,528 & 0,000 \\
\hline
\end{tabular}

-The effect is statistically significant at level $(a \leq 0,05)$

Table results indicate that the value of $(\mathrm{r}=0,441)$, which means that there is a positive relationship between Training Process Stages and Employees Performance. 
The value of Determination Coefficient is $\left(\mathrm{R}^{2}=0,194\right)$, this means that the dimension of training stages explained $(19,4 \%)$ of variance in Employees Performance with the stability of other factors. it is also shown that the value of $(F)$ has reached (42.615) at the level of confidence ( $\mathrm{Sig}=0,000)$, this confirms regression level at $(\mathrm{a} \leq 0,05)$.

\section{2-H: There is no statistical significance effect for the diversity of training programs on employees' performance} at Amman Municipality

The table (3): results of the impact test of the dimension of (diversity of training programs) on Employees Performance

\begin{tabular}{|l|l|l|l|l|l|l|l|l|l|}
\hline \multirow{2}{*}{$\begin{array}{l}\text { Dependent } \\
\text { variable }\end{array}$} & $\begin{array}{l}\text { Model summery } \\
\text { Pearson } \\
\begin{array}{l}\text { Correlation } \\
\text { Coefficient }\end{array}\end{array}$ & $\begin{array}{l}\mathrm{R}^{2} \\
\text { determination } \\
\text { coefficient }\end{array}$ & $\begin{array}{l}\text { Calculated } \\
\mathrm{F}\end{array}$ & Sig F & variance & $\mathrm{B}$ & $\begin{array}{l}\text { Stand } \\
\text { ard } \\
\text { error }\end{array}$ & $\begin{array}{l}\text { Calculated } \\
\mathrm{T}\end{array}$ & Sig t \\
\hline $\begin{array}{l}\text { employees } \\
\text { performance }\end{array}$ & 0,459 & 0,211 & 47,319 & 0,000 & $\begin{array}{l}\text { diversity of } \\
\text { training } \\
\text { programs }\end{array}$ & 0,323 & 0,047 & 6,879 & 0,000 \\
\hline
\end{tabular}

The effect is a statistical significant at level $(a<0,05)$

Table results indicate that the value of $(\mathrm{r}=0,459)$, which means that there is a positive relationship between diversity of training programs dimension and the employees performance. The value of determination coefficient is $\left(\mathrm{R}^{2}=0,211\right)$, this means that the dimension of diversity of training programs explained $(21,1 \%)$ of variance in the employees performance with the stability of other factors. It is also shown that the value of $(\mathrm{F})$ has reached $(47,319)$ at the level of confidence ( $\mathrm{Sig}=0,000)$, this confirms regression level at $(\mathrm{a} \leq 0,05)$.

\section{3-H: There is no statistical significance effect of adopting \& using modern technologies of training on employees'} performance at Amman's Municipality.

The table (4): results of the impact test of the dimension of (adopting and using modern technologies) on the employees performance

\begin{tabular}{|l|l|l|l|l|l|l|l|l|l|}
\hline \multirow{2}{*}{$\begin{array}{l}\text { Dependent } \\
\text { variable }\end{array}$} & Model summery & ANOVA & \multicolumn{2}{l|}{ Coefficient } \\
\cline { 2 - 9 } & $\begin{array}{l}\text { Pearson } \\
\text { Correlation } \\
\text { Coefficient }\end{array}$ & $\begin{array}{l}\mathrm{R}^{2} \\
\text { determinati } \\
\text { on } \\
\text { coefficient }\end{array}$ & $\begin{array}{l}\text { Calculated } \\
\mathrm{F}\end{array}$ & $\begin{array}{l}\text { Sig } \\
\mathrm{F}\end{array}$ & variance & $\mathrm{B}$ & $\begin{array}{l}\text { Standard } \\
\text { error }\end{array}$ & $\begin{array}{l}\text { Calculated } \\
\mathrm{T}\end{array}$ & Sig t \\
\hline $\begin{array}{l}\text { employees } \\
\text { performance }\end{array}$ & 0,401 & 0,161 & 34,002 & $\begin{array}{l}0,00 \\
0\end{array}$ & $\begin{array}{l}\text { adopting and } \\
\text { using modern } \\
\text { technology }\end{array}$ & $\begin{array}{l}0,31 \\
3\end{array}$ & 0,054 & 5,831 & 0,000 \\
\hline
\end{tabular}

The effect is a statistical significant at level $(\mathrm{a}<0,05)$

Table results indicate that the value of $(\mathrm{r}=0,401)$, which means that there is a positive relationship between adopting and using modern technology dimension and the performance of workers. The value of determination coefficient is $\left(\mathrm{R}^{2}=0,161\right)$, this means that the adopting and using modern technology dimension explained $(16,1 \%)$ of variance in the employees performance with the stability of other factors. It is also shown that the value of $(\mathrm{F})$ has reached $(34,002)$ at the level of confidence ( $\mathrm{Sig}=0,000)$, this confirms regression level at $(\mathrm{a} \leq 0,05)$.

4-H: There is no statistical effect at significance level of Support and commitment of senior management on employees' performance at Amman's Municipality.

The table (5): results of the impact test of the dimension of (Support and commitment of senior management) on the employee's performance

\begin{tabular}{|c|c|c|c|c|c|c|c|c|c|}
\hline \multirow{2}{*}{$\begin{array}{l}\text { Dependent } \\
\text { variable }\end{array}$} & \multicolumn{2}{|c|}{ Model summery } & \multicolumn{2}{|l|}{ ANOVA } & \multicolumn{5}{|l|}{ Coefficient } \\
\hline & $\begin{array}{l}\mathrm{R} \\
\text { Pearson } \\
\text { Correlation } \\
\text { Coefficient }\end{array}$ & $\begin{array}{l}\mathrm{R}^{2} \\
\text { determinati } \\
\text { on } \\
\text { coefficient }\end{array}$ & $\begin{array}{l}\text { Calculate } \\
\text { d } \\
\text { F }\end{array}$ & Sig F & variance & B & $\begin{array}{l}\text { Standard } \\
\text { error }\end{array}$ & $\begin{array}{l}\text { Calculated } \\
\mathrm{T}\end{array}$ & Sig t \\
\hline $\begin{array}{l}\text { employees } \\
\text { performance }\end{array}$ & 0,465 & 0,216 & 48,892 & 0,000 & $\begin{array}{l}\text { senior } \\
\text { management } \\
\text { support }\end{array}$ & 0,319 & 0,046 & 6,992 & 0,000 \\
\hline
\end{tabular}

The effect is a statistical significant at level $(a<0,05)$ 
Table results indicate that the value of $(\mathrm{r}=0,465)$, which means that there is a positive relationship between senior management support dimension and employees performance. The value of determination factor is $\left(\mathrm{R}^{2}=0,216\right)$, this means that the senior management support dimension explained $(21,6 \%)$ of variance in the employees performance with the stability of other factors. It is also shown that the value of $(\mathrm{F})$ has reached $(48,892)$ at the level of confidence (Sig=0,000), this confirms regression level at $(\mathrm{a} \leq 0,05)$.

\section{Results}

1-There is statistical significant impact at significance level $(a \leq 0,05)$ for training strategy on performance of workers in Municipality of Amman

2-the results indicated that $(36,7 \%)$ of variation in performance of workers can be explained by the impact of training strategy.

\section{Recommendations}

1-Determine the training requirement for all employees in Municipality of Amman.

2-Develop the classrooms and provide it with appropriate and modern training tools.

3 -Increase the current training budget and raise the rewards of trainers

4-Benefit from the experienced staff in Municipality of Amman because they have the knowledge and experience necessary to accomplish the works that require special skills.

5-Benefit from the experiences of similar organizations in training strategies field.

6- Having various Training programs inside and outside Municipality of Amman and hire efficient trainers.

\section{References}

Guest, D. E. (2011). Human resource management and performance: still searching for some answers. Human Resource Management Journal, 21 (1), 3-13.

Datta, D. K., Guthrie, J. P. \& Wright, P. M. (2005).Human resource management and laborproductivity: Does industry matter? Academy of Management Journal, Vol. 48(1), 135 - 145.

Armstrong M.A. (2009)A Handbook of Human Resources Management (1 ${ }^{\text {th }}$ ed ).London : Kogan Page.

Boudreau, J. W, \& Ramstad, P. M. (2003). Strategic HRM measurement in the 21st century: From justifyingHR to strategic talent leadership. In M. Goldsmith, R. P. Gandossy, \& M. S. Efron (Eds.), MMin the 21st Century (pp. 79-90). New York: Wiley.

Fombrun, C., Tichy, N.M., and Devanna, M.A. (2015), Strategic Human ResourceManagement, New York: John Wiley.

Armstrong, M. (2006). Performance management: key strategies and practical guidelines. $3^{\text {th }}$ edition. Kogan Page Limited

Wilson, J. P. (1999). Human resource development. Learning and training for individuals and organizations. London, Kogan Page.

Richard P. J., Devinney T. M., Yip G.S., \& Johnson G. (2009). Measuring organizational performance: Towards methodological best practice. Journal Management, 35 (3), 718-804 .

Thomas, K. W. (2000). Intrinsic motivation at work: Building energy and commitment. San Francisco: Berrett-Koehler Publisher, Inc

Snow, C.C. \& Snell, S.A. 1992. Staffing as strategy. In N. Schmitt, W. Borman \& Associates (Eds.) Personnel Selection in Organizations San Francisco, CA Jossey-Bass.

Youndt M.A., Snell S.A., Dean J.W \& Lepak D.P., (1996), "Human resource management, manufacturing strategy, and performance", Academy of Management Journal, Aug, Vol 39. pp 836-866. 